\title{
COMMERCIALIZATION OF THE STATE UNIVERSITY: WHY THE INTELLECTUAL PROPERTY PROTECTION RESTORATION ACT OF 2003 IS NECESSARY
}

\author{
TRACI DREHER QUIGLEY ${ }^{\dagger}$
}

\section{INTRODUCTION}

At first blush, major state universities and colleges appear to be well-balanced with their private counterparts: Each contains strong academic programs with Nobel Laureates and other notable scholars in their research labs and lecture halls; each fields large numbers of strong sports teams; and each benefits from the current federal intellectual property rights regime, whereby valuable patents, copyrights, and trademarks have been claimed. Despite this apparent parity, however, state universities have a surprising economic advantage over private universities-state universities can profit from their Eleventh Amendment immunity against damage claims for intellectual property infringement. Private institutions are not similarly immune.

This disparate treatment of intellectual property rights is particularly important because of several recent cases involving universities (both public and private) against private entities. Two noteworthy examples include litigation by the University of Rochester against G.D. Searle \& Co. (Pharmacia) for the alleged infringement of the University's patent on the Cox-2 enzyme ${ }^{1}$ and John Madey's claim against Duke University concerning the alleged infringement of his patents

B.A. 1998, Duke University; J.D. Candidate 2004, University of Pennsylvania. I wish to thank Professor Arti K. Rai, Duke Law School, for her valuable feedback and suggestions for improvement and Robert Ballenger, John Eustice, Jodi Rosensaft, and Chris Seaman for their insightful comments. Notwithstanding their tireless efforts, all errors that remain are my own.

${ }^{1}$ Univ. of Rochester v. G.D. Searle \& Co., 249 F. Supp. 2d 216 (W.D.N.Y. 2003), aff'd, 358 F.3d 916 (Fed. Cir. 2004); see also Goldie Blumenstyk, Taking on Goliath: U. of Rochester Risks Millions in Patent Fight with Pharmaceutical Giants, CHRON. HigHER EDUC., Sept. 20, 2002, at A27 (discussing the University of Rochester's patent infringement suit against the maker of Celebrex, a Cox-2-inhibitor drug); Margaret Cronin Fisk, Ivory Towers Fire Back over Patent, NAT'L L.J., Aug. 26, 2002, at A1, A7 (detailing several lawsuits, including the University of Rochester suit, by universities against private parties for intellectual property infringement). 
on laboratory equipment. ${ }^{2}$ Since the universities in both of these cases are private entities, neither case involved sovereign immunity. However, had either school been a state university, the cases would have involved an additional layer of complexity.

Since the early 1990s, there have been numerous congressional attempts to remedy the imbalances caused by the Eleventh Amendment's sovereign immunity. ${ }^{3}$ Of these, two laws were found unconstitutional by the Supreme Court, ${ }^{4}$ and several other proposals have died on the congressional floor. Undaunted, Senator Patrick Leahy of Vermont has submitted a bill, the Intellectual Property Protection Restoration Act of $2003,{ }^{5}$ to rectify the unfairness of the existing doctrine of sovereign immunity as applied to the federal intellectual property rights regime. Although it has undergone significant alterations since it was initially proposed in $1999,{ }^{6}$ the Intellectual Property Protection Restoration Act should be supported and adopted by all those concerned with intellectual property rights.

In this Comment, I argue that the tightening of permitted behavior under the intellectual property statutes, when coupled with the current incentives and priorities of universities, requires a change to the state universities' immunity from damages in infringement cases. Part I briefly summarizes the relationship between universities and intellectual property rights. Historically, both public and private universities understood that they were subject to the same set of intellectual

\footnotetext{
${ }^{2}$ Madey v. Duke Univ., 307 F.3d 1351 (Fed. Cir. 2002), cert. denied, 123 S. Ct. 2639 (2003).

See infra text accompanying notes 54, 80, 90 (discussing, respectively, the Indian Gaming Regulatory Act, 25 U.S.C. $\$ \S 2701-2721$ (2000); the Patent and Plant Variety Protection Remedy Clarification Act, 7 U.S.C. $\$ \S 2541$ (a)-(b), 2570 (2000), 35 U.S.C. $\S \S 271(\mathrm{~h}), 296$ (2000); and the Trademark Remedy Clarification Act, 15 U.S.C. $\$ \S$ $1114,1122,1125,1127(2000))$.

${ }^{4}$ See infra text accompanying notes 80-90 (referring to the invalidation of the Patent and Plant Variety Protection Remedy Clarification Act § 2(a), 35 U.S.C. § 271(h), by Florida Prepaid Postsecondary Education Expense Board v. College Savings Bank, 527 U.S. 627 (1999), and the invalidation of the Trademark Remedy Clarification Act $\S 3,15$ U.S.C. § 1122, by College Savings Bank v. Florida Prepaid Postsecondary Education Expense Board, 527 U.S. 666 (1999)).

${ }^{5}$ Intellectual Property Protection Restoration Act of 2003, S. 1191, 108th Cong. (2003). A similar bill was introduced in the House of Representatives by Rep. Lamar Smith of Texas and Rep. Howard Berman of California. Intellectual Property Protection Restoration Act of 2003, H.R. 2344, 108th Cong. (2003). Senator Leahy also introduced an identical bill, S. 2031, in the previous Congress. Intellectual Property Protection Restoration Act of 2002, S. 2031, 107th Cong. (2002).

${ }^{6}$ Intellectual Property Protection Restoration Act of 1999, S. 1835, 106th Cong.
} (1999). 
property laws, including monetary damages for infringement. Part II reviews the development and evolution of state sovereign immunity case law, with particular emphasis on cases involving intellectual property. The lesson from recent cases is that state universities are unequivocally immune from intellectual property damage remedies. The importance of state university immunity is considered in Part III, which presents several reasons why such immunity is not appropriate. Part IV discusses possible solutions, including Senator Leahy's proposal, which are currently being debated by legislators and vetted by scholars. Finally, Part V analyzes and recommends the adoption of Senator Leahy's bill and explains why state universities and other interested parties should support it.

\section{UNIVERSITIES AND INTELLECTUAL PROPERTY}

"A university should be a place of light, of liberty, and of learning." These words, spoken by Benjamin Disraeli to the House of Commons in 1873, continue to resonate today. American universities-both public and private-are the sanctuaries of great minds, innovative ideas, and intellectual opportunity.

It is unsurprising, then, that universities have parlayed these strengths into intellectual property rights and economic benefits. Current data suggests that universities hold over 22,500 patents, with 13,000 of these held by public universities and colleges. ${ }^{8}$ The United States Patent and Trademark Office (USPTO) has calculated that at least $2.5 \%$ of all issued utility patents are currently owned by state academic institutions. ${ }^{9}$ Furthermore, four-year state colleges and universities have registered over 32,000 monographs with the United States Copyright Office since $1978,{ }^{10}$ and it has also been estimated that they

\footnotetext{
${ }^{7}$ Benjamin Disraeli, Address to the House of Commons (Mar. 11, 1873), quoted in JOHN BARTLETT, FAMILIAR QUOTATIONS 502 (Emily Morison Beck ed., 15th ed. 1980).

${ }^{8}$ State Sovereign Immunity and Protection of Intellection Property: Hearing Before the Subcomm. on Courts $\mathcal{E}$ Intellectual Prop. of the House Comm. on the Judiciary, 106th Cong. 9 (2000) [hereinafter Hearing on State Sovereign Immunity] (statement of Todd Dickinson, Under Secretary of Commerce for Intellectual Property; Director, United States Patent and Trademark Office) (providing the results of the USPTO's empirical research into state ownership of intellectual property).

${ }^{9}$ Id. at 9 (statement of Todd Dickinson, Under Secretary of Commerce for Intellectual Property; Director, United States Patent and Trademark Office).

${ }^{10} I d$. at 15 (statement of Marybeth Peters, Register of Copyrights, U.S. Copyright Office) (noting the number of copyrights registered by four-year public colleges and universities).
} 
own over 2700 trademarks. ${ }^{11}$ The monetary value of this intellectual property is realized through licensing and technology transfer arrangements, whereby a university licenses its intellectual property to another entity. In fiscal year 2002, according to the Association of University Technology Managers, public and private universities received almost one billion dollars in gross license income from their intellectual property. ${ }^{12}$

Such lucrative licensing opportunities illustrate the increasing importance and utility of university research to private enterprise that the Bayh-Dole Act ${ }^{13}$ was meant to foster. ${ }^{14}$ As a result of the Act, public-private collaborations have developed and commercialized novel technologies like enhanced cellular voice quality and improved commodity products such as cleaner electricity. ${ }^{15}$ Indeed, in this cooperative environment, it was rare for patent infringement suits to be brought against academic institutions, since most technologies were made available to academic researchers under reasonable terms-e.g., at low cost and with acceptable restrictions on use. ${ }^{16}$

Another reason that such suits were few and far between was the parity between universities and commercial patent-holders with regard to damage remedies in infringement suits. As described by the

${ }^{11}$ U.S. Gen. ACCOUNTING OfFice, InTEllectual Property: STATE IMMUnity IN INFRINGEMENT ACTIONS 43-44 app.II at tbl.4 (2001).

${ }^{12}$ Ass'N OF Univ. TeCH. MANAGERS, AUTM LiCENSING SuRveY: FY 2002, at 62 (2003), available at $\mathrm{http}: / /$ www.autm.net.

${ }^{13}$ Act of Dec. 12, 1980, Pub. L. No. 96-517, 94 Stat. 3015 (codified as amended at 17 U.S.C. $\$ 117$ (2000), 35 U.S.C. \$§ 41-42, 200-211, 301-307 (2000)) (commonly referred to as the Bayh-Dole Act).

${ }^{14}$ The Bayh-Dole Act encourages entities receiving federal funds to obtain patents for their inventions. Since its passage, there has been a dramatic increase in the number of patents pursued by universities. Although a fuller discussion of the Bayh-Dole Act is beyond the scope of this Comment, a robust explanation and overview of the Act and its impact may be found in Rebecca S. Eisenberg, Public Research and Private Development: Patents and Technology Transfer in Government-Sponsored Research, 82 VA. L. REV. 1663 (1996).

${ }^{15}$ See Ass'N OF Univ. TeCH. MANAGERS, supra note 12, at 4-5 (describing the new technology for improved sound capture and noise reduction in cell phones, hearing aids, and other electronic devices developed by Carnegie Mellon University, now licensed to Akustica Inc., and the invention of a new plasma electric generator to produce low-cost clean electricity by researchers at the University of California-Irvine and University of Florida, now licensed to Tri Alpha Energy).

${ }^{16}$ See Utility Examination Guidelines, 66 Fed. Reg. 1092, 1096 (Jan. 5, 2001) (commenting on the rarity of infringement suits by commercial patent owners against academics because of the "favorable licensing terms"). 
$\mathrm{USPTO}^{17}{ }^{17}$ the Copyright Office, ${ }^{18}$ congressional investigators, ${ }^{19}$ and even the National Association of College and University Attorneys, ${ }^{20}$ everyone shared the belief that state universities (as well as other state entities) were subject to intellectual property infringement suits and remedies. The consequence was implicit but sweeping: All intellectual property holders were assured the protection of their invention, creation, or trademark against any possible infringer, including a state university. It was widely understood that if a state entity infringed upon a patent, copyright, or trademark, the holder could seek not only injunctive but also monetary relief.

This bedrock of understanding was shaken to its core in 1999, when the Supreme Court ended its decade-long erosion of private individuals' rights against intellectual property infringement by state entities.

\section{EVOLUTION OF SOVEREIGN IMMUNITY DOCTRINE}

\section{A. Common Law Development and Revolution}

Understanding the historical development of sovereign immunity is important to any analysis of the Supreme Court's recent decisions regarding state immunity in the intellectual property regime. ${ }^{21}$ The

${ }^{17}$ Hearing on State Sovereign Immunity, supra note 8, at 10 (statement of Todd Dickinson, Under Secretary of Commerce for Intellectual Property; Director, United States Patent and Trademark Office) (explaining that when Congress passed the Bayh-Dole Act, the USPTO believed "that state instrumentalities were amenable to damage suits for violation of intellectual property on the same terms as private actors").

${ }^{18} I d$. at 16 (statement of Marybeth Peters, Register of Copyright, U.S. Copyright Office) (testifying that "[f] or most of our history, it has been assumed that the States enjoyed no special immunity from suits for infringement of intellectual property rights").

${ }^{19}$ See U.S. Gen. Accounting Office, supra note 11, at 24 (reporting that there have not been many cases of past state infringement because "states previously were of the opinion they could be sued for damages in federal court-a situation that no longer exists").

${ }^{20}$ Nat'l Ass'n of Coll. \& Univ. Attorneys, Critique of Objections to S. 2031, at 1, at http://www.nacua.org/documents/2031responsetouniversities.pdf (last visited Apr. 30,2004 ) (explaining that " $[\mathrm{u}]$ ntil recently, it was understood and accepted" that all states were "liable for monetary relief for infringements of federally protected intellectual property").

${ }^{21}$ Numerous scholars have chronicled the colorful history of sovereign immunity and its role in intellectual property. See generally Mitchell N. Berman et al., State Accountability for Violations of Intellectual Property Rights: How to "Fix" Florida Prepaid (And How Not To), 79 TEX. L. Rev. 1037, 1044-51 (2001); Christina Bohannan, Beyond Abrogation of Sovereign Immunity: State Waivers, Private Contracts, and Federal Incentives, 77 N.Y.U. 
Supreme Court's decision in Chisholm v. Georgia ${ }^{22}$ was the impetus for a constitutional amendment regarding the scope of state sovereign immunity. In Chisholm, a South Carolina creditor brought suit against the State of Georgia for repayment of debt. ${ }^{23}$ In its ruling for Chisholm, the Court held that the Constitution provided the federal judiciary with jurisdiction over all cases arising between a state and citizens of another state. $^{24}$ In response, Congress passed and the states ratified the Eleventh Amendment, which restored sovereign immunity for the states against out-of-state private litigants. ${ }^{25}$

A century after adoption of the Eleventh Amendment, the Supreme Court heard its second seminal case concerning private suits against a state. In Hans $v$. Louisiana, ${ }^{26}$ the plaintiff sued the State of Louisiana for refusing to redeem his bond coupons. ${ }^{27}$ The plaintiff, a citizen of Louisiana, contended that the Eleventh Amendment did not apply because it only prevented suits based on diversity of citizenship, not suits where the plaintiff was a citizen of the defendant state. ${ }^{28}$ The Court rejected the plaintiff's argument, holding that the Eleventh Amendment prohibited all private suits against a state. ${ }^{29}$ Indeed, the Court reached back further than the origins of the Eleventh Amendment to the early writings of Alexander Hamilton and other "great defenders of the Constitution" who criticized the idea of allowing a nonconsenting state to be sued by any individual. ${ }^{30}$ Following Hans, a state was immune from private actions unless it consented to the suit.

Obtaining consent was made easier after Parden v. Terminal Railway of Alabama State Docks Department, ${ }^{31}$ which acknowledged that there could be implied waivers of sovereign immunity. In Parden, employees

L. REv. 273, 278-81 (2002); John T. Cross, Suing the States for Copyright Infringement, 39 BRANDEIS L.J. 337, 342-55 (2000); Steve Malin, The Protection of Intellectual-Property Rights in a Federalist Era, 6 COMPUTER L. REV. \& TECH. J. 137, 139-63 (2002).

${ }^{22} 2$ U.S. (2 Dall.) 419 (1793).

${ }^{23} I d$. at 429-30 (Iredell, J., dissenting).

${ }^{24}$ Id. at 467-68 (Cushing, J.).

${ }^{25}$ U.S. CONST. amend. XI. The Eleventh Amendment provides that "[t] he Judicial power of the United States shall not be construed to extend to any suit in law or equity, commenced or prosecuted against one of the United States by Citizens of another State, or by Citizens or Subjects of any Foreign State." Id.

${ }^{26} 134$ U.S. 1 (1890).

${ }^{27} \mathrm{Id}$. at $2-8$.

${ }^{28} \mathrm{Id}$. at $6-7$.

${ }^{29} I d$. at 15 .

${ }^{30} I d$. at 12-14 (citing THE FEDERALIST No. 81 (Alexander Hamilton)); see also id. at 14 (discussing statements by James Madison and John Marshall).

31377 U.S. 184 (1964). 
of the state-run railway brought suit under the Federal Employers' Liability Act (FELA) ${ }^{32}$ for damages caused by work-related personal injury. ${ }^{33}$ The State of Alabama argued that it was immune from liability under the Eleventh Amendment and rejected the employee claims. ${ }^{34}$ After considering prior case law, including Hans, the Court ruled for the employees, holding that the Commerce Clause implicitly waived state sovereign immunity regarding the regulation of commerce. The Court stated that "[b]y empowering Congress to regulate commerce ... the States necessarily surrendered any portion of their sovereignty that would stand in the way of such regulation... . [I]t must follow that application of [FELA] to such a railroad cannot be precluded by sovereign immunity. ${ }^{, 35}$

Parden's impact on the sovereign immunity doctrine was relatively short-lived, however, because it was overruled by the Supreme Court in 1985. In Atascadero State Hospital v. Scanlon, ${ }^{36}$ the Court held that implied waivers of state immunity would not be recognized. ${ }^{37}$ Plaintiff Scanlon brought the suit for monetary damages under section 504 of the Rehabilitation Act, ${ }^{38}$ but the California state hospital argued that it was immune from suit under the Eleventh Amendment. ${ }^{39}$ The Court agreed with the hospital, holding that the Rehabilitation Act did not abrogate California's Eleventh Amendment immunity. ${ }^{40}$ According to the Court, a state may only waive its immunity by making an "unequivocal indication that the State intends to consent to federal jurisdiction that would otherwise be barred by the Eleventh Amendment." ${ }^{41}$ Likewise, Congress may only abrogate state immunity if it provides an "unequivocal expression of congressional intent to 'overturn the constitutionally guaranteed immunity of the several States."

3245 U.S.C. $\$ \S 51-60(2000)$.

33 Parden, 377 U.S. at 184-85.

${ }^{34}$ See id. at 186 ("Respondents rely, as did the lower courts in dismissing the action, on sovereign immunity ....").

${ }^{35} I d$. at 192.

36473 U.S. 234 (1985).

${ }^{37}$ See id. at 238-40 (stating that although there are limits to sovereign immunity, a state's waiver of immunity will only be recognized when expressly made).

38 U.S.C. $\$ 794$ (2000).

${ }^{39}$ Atascadero, 473 U.S. at 236.

${ }^{40} I d$. at 246.

${ }^{41} I d$. at 238 n.1.

${ }^{42}$ Id. at 240 (quoting Pennhurst State Sch. \& Hosp. v. Halderman, 465 U.S. 89, 99 (1984)); see also Welch v. Tex. Dep't of Highways \& Pub. Transp., 483 U.S. 468, 478 (1987) ("Accordingly, to the extent that Parden ... is inconsistent with the requirement 
The result of Atascadero, then, was to eviscerate the implied waiver theory and to establish a clear test for determining when immunity has been waived.

Four years after Atascadero, the Court once again delivered a holding that would later be overturned in subsequent years. In Pennsylvania v. Union Gas Co., ${ }^{43}$ the Supreme Court was presented with a thirdparty complaint by Union Gas against the Commonwealth of Pennsylvania under the Comprehensive Environmental Response, Compensation, and Liability Act (CERCLA) ${ }^{44}$ for shared liability for hazardous waste clean-up costs. ${ }^{45}$ Pennsylvania denied liability, claiming that it was immune from suit under the Eleventh Amendment. ${ }^{46}$ This argument was adopted by both the district and circuit courts, which found no clear expression of congressional intent to waive sovereign immunity. ${ }^{47}$ The Supreme Court disagreed, however, and held that Pennsylvania was liable for sharing the cost of the clean up. ${ }^{48}$ In its analysis, the Court first looked for, and found, clear intent by Congress in CERCLA to abrogate state sovereign immunity for damage claims. ${ }^{49}$ In the second half of its analysis, the Court upheld Congress's authority to abrogate state immunity under its Commerce Clause powers. ${ }^{50}$ This latter finding was buttressed by referring to Parden $^{51}$ and analogizing Congress's right to abrogate immunity under the Fourteenth Amendment with its ability to do so under the Commerce Clause. ${ }^{52}$ Consequently, the result was that Congress could abrogate immunity under its Article I powers.

\footnotetext{
that an abrogation of Eleventh Amendment immunity by Congress must be expressed in unmistakably clear language, it is overruled.").

43491 U.S. 1 (1989).

44 U.S.C. $\$ \$ 9601-9675$ (2000).

${ }^{45}$ Union Gas Co., 491 U.S. at 6.

${ }^{46} I d$.

${ }^{47}$ See id. (citing the lower courts' holdings in United States v. Union Gas Co., 832 F.2d 1343 (3d Cir. 1987), and United States v. Union Gas Co., 575 F. Supp. 949 (E.D. Pa. 1983), that Union Gas's suit was barred under the Eleventh Amendment).

${ }^{48} I d$. at 23.

${ }^{49}$ See id. at 7-13 (holding that "CERCLA clearly permits suits for money damages against States in federal court").

${ }^{50} I d$. at $14-19$.

${ }^{51}$ Id. at 14.

${ }^{52}$ See id. at 16-17 (noting that, "[1]ike the Fourteenth Amendment, the Commerce Clause with one hand gives power to Congress while, with the other, it takes power away from the States").
} 
Mirroring the reversal seen in both Parden and Atascadero, Union Gas was soon overruled by the Supreme Court in Seminole Tribe v. Florida. ${ }^{53}$ There, the Court decided whether the Indian Commerce Clause, under Article I of the Constitution, provided Congress with authority to abrogate state immunity in the Indian Gaming Regulatory Act. ${ }^{54}$ The Court overruled its decision in Union Gas, holding that Congress could not rely on its Article I powers to abrogate state immunity, even with a clearly expressed intent to do so. ${ }^{55}$ Following this decision, the only remaining authority for congressional abrogation of state immunity lay within Section 5 of the Fourteenth Amendment. ${ }^{56}$

As several commentators have noted, ${ }^{57}$ Congress's power to abrogate immunity under even the Fourteenth Amendment was brought into question after the Supreme Court's decision in City of Boerne $v$. Flores. $^{58}$ This case concerned the constitutionality of the Religious Freedom Restoration Act (RFRA), ${ }^{59}$ which required states to make specific findings before adopting laws that "substantially burden" an individual's religious practices. ${ }^{60}$ Although the case did not deal with state immunity per se, the Court ruled that Congress could only use Section 5 of the Fourteenth Amendment as a "remedial" power for enforcing that Amendment's provisions. ${ }^{61}$ The Court established a test for determining when this remedial power is properly used, holding that " $[\mathrm{t}]$ here must be a congruence and proportionality between the injury to be prevented or remedied and the means adopted to that end." ${ }^{62}$ Considering the RFRA, the Court concluded that the statute

53517 U.S. 44 (1996).

54 U.S.C. $\$ \S 2701-2721$ (2000).

${ }^{55}$ Seminole Tribe, 517 U.S. at 66 ("We feel bound to conclude that Union Gas was wrongly decided and that it should be, and now is, overruled.").

${ }^{56} I d$. at 59 (referring to the Court's holding in Fitzpatrick v. Bitzer, 427 U.S. 445, 452-56 (1976), which recognized the Fourteenth Amendment as a source of authority to abrogate state immunity); see also Nev. Dep't of Human Res. v. Hibbs, 123 S. Ct. 1972 (2003) (holding that the Family and Medical Leave Act of 1993, 5 U.S.C. $§ \S 6381-6387$ (2000), 29 U.S.C. $\$ \$ 2601-2654$ (2000), validly abrogated state sovereign immunity under Section 5 of the Fourteenth Amendment).

57 See, e.g., Malin, supra note 21, at 154 (classifying the City of Boerne decision as "a serious blow" to "Congress's power to legislate under Section 5 of the Fourteenth Amendment").

58 521 U.S. 507 (1997).

5942 U.S.C. $\$ \S 2000$ bb to 2000 bb-4 (2000).

${ }^{60} 521$ U.S. at 515 .

${ }^{61} I d$. at 519 (quoting South Carolina v. Katzenbach, 383 U.S. 301, 326 (1966)).

${ }^{62} I d$. at 520 . 
lacked these characteristics and thus was unconstitutional under the Fourteenth Amendment. ${ }^{63}$

Most recently, the test articulated in City of Boerne was applied and found to be satisfied by the Court in Nevada Department of Human Resources $v$. Hibbs. ${ }^{64}$ In Hibbs, the Court determined that when enacting the family-leave provision of the Family and Medical Leave Act of 1993 (FMLA), ${ }^{65}$ Congress had properly abrogated the State's sovereign immunity through a valid exercise of its power under Section 5 of the Fourteenth Amendment. ${ }^{66}$ Under the FMLA, employees may "seek both equitable relief and money damages 'against any employer (including a public agency) in any Federal or State court of competent jurisdiction' . . . should that employer 'interfere with, restrain, or deny the exercise of' FMLA rights." ${ }^{67}$ The Court concluded that Congress had sufficient evidence to conclude that state laws and policies regarding family leave "were applied in discriminatory ways" had been participating in "gender-based discrimination in the administration of leave benefits." ${ }^{\circ 9}$ Because gender-based differentiation is subject to heightened scrutiny, the Court found that Congress was justified in passing "prophylactic $\$ 5$ legislation" ${ }^{, 70}$ and that such legislation was "congruent and proportional to its remedial object.",

Finally, in 1999, the Supreme Court articulated the last three principles of its modern sovereign immunity jurisprudence. The first principle concerned the question whether the Eleventh Amendment barred suits against the state in both federal and state courts. In Alden v. Maine, ${ }^{72}$ the Court responded in the affirmative. There, a group of probation officers brought an action against the State of Maine for alleged violations of the Fair Labor Standards Act (FLSA). ${ }^{73}$ The case had been dismissed by lower courts-both federal and state-because

${ }^{63}$ Id. at $532-33$.

64123 S. Ct. 1972, 1982-84 (2003).

655 U.S.C. $\$ \$ 6381-6387$ (2000), 29 U.S.C. $\$ \$ 2601-2654$ (2000).

${ }^{66}$ See Hibbs, 123 S. Ct. at 1984 (concluding that the Family and Medical Leave Act "is congruent and proportional to its remedial object[ive], and can 'be understood as responsive to or designed to prevent, unconstitutional behavior" (quoting City of Boerne, 521 U.S. at 532)).

${ }^{67} I d$. at 1976 (quoting 29 U.S.C. $§ \S 2617$ (a) (2), 2615 (a) (1) (2000)).

${ }^{68} I d$. at 1980.

${ }^{69} I d$. at 1981 .

${ }^{70} I d$. at 1979 .

${ }^{71} I d$. at 1984.

${ }^{72} 527$ U.S. 706 (1999).

7329 U.S.C. $§ \S 201-219$ (2000). 
of Maine's right to immunity under the Eleventh Amendment. ${ }^{74}$ Refusing to accept the Petitioner's arguments to the contrary, the Court held that "[i]n light of history, practice, precedent, and the structure of the Constitution, we hold that the States retain immunity from private suit in their own courts, an immunity beyond the congressional power to abrogate by Article I legislation." 75

The second and third principles of the Court's modern jurisprudence were established in two companion cases: Florida Prepaid Postsecondary Education Expense Board v. College Savings Bank ${ }^{76}$ and College Savings Bank v. Florida Prepaid Postsecondary Education Expense Board. ${ }^{77}$ Each case concerned a tuition savings plan marketed by College Savings Bank, a New Jersey bank, for financing the costs of higher education. $^{78}$ In its original suit against Florida Prepaid Postsecondary Education Expense Board, a state agency that administered prepayment tuition programs for Florida's public colleges and universities, the Bank alleged that the Board infringed its patent on the savings plan's financial methodology and made misstatements concerning its own savings plan. ${ }^{79}$ The two issues were split on appeal, but the Supreme Court published both opinions on the same day.

In Florida Prepaid, the Court addressed the constitutionality of the Patent and Plant Variety Protection Remedy Clarification Act (PRCA).$^{80}$ Passed in 1992, the PRCA responded to Atascadero and related lower federal court decisions ${ }^{81}$ by including an unequivocal expression of Congress's intent to abrogate immunity. ${ }^{82}$ Despite finding that Congress clearly intended to abrogate immunity for intellectual property infringement, ${ }^{83}$ the Court held in Florida Prepaid that the PRCA did not satisfy the requirements established in City of Boerne and

74 Alden, 527 U.S. at 712.

Id. at 754 .

76527 U.S. 627 (1999).

77527 U.S. 666 (1999).

78 College Savings Bank, 527 U.S. at 670-71; Florida Prepaid, 527 U.S. at 630.

79 College Savings Bank, 527 U.S. at 671; Florida Prepaid, 527 U.S. at 631.

${ }^{80} 7$ U.S.C. $\$ \$ 2541$ (a)-(b), 2570 (2000), 35 U.S.C. $\$ \$ 271$ (h), 296 (2000).

81 See, e.g., BV Eng'g v. Univ. of Cal., 858 F.2d 1394, 1400 (9th Cir. 1988) (relying on Atascadero to determine that Congress did not intend to hold nonconsenting states liable in federal court for damages under the Copyright Act); Kersavage v. Univ. of Tenn., 731 F. Supp. 1327, 1330 (E.D. Tenn. 1989) (holding that a state university was immune from damages for patent infringement).

${ }^{82}$ Florida Prepaid, 527 U.S. at 635 ("[I]n enacting the Patent Remedy Act, Congress has made its intention to abrogate the States' immunity 'unmistakably clear in the language of the statute." (quoting Dellmuth v. Muth, 491 U.S. 223, 228 (1989))).

Id. 
thus was unconstitutional. ${ }^{84}$ First, the Court noted that the legislative record did not hold evidence of "a history of "widespread and persisting deprivation of constitutional rights' of the sort Congress has faced in enacting proper prophylactic Section 5 legislation. ${ }^{, 5}$ Second, the provisions of the PRCA were deemed disproportionate to any behavior that Congress was trying to prevent. ${ }^{86}$ In summary, the second principle in our modern jurisprudence is the stringent proportionality test set forth in City of Boerne and Florida Prepaid to abrogate a state's Eleventh Amendment immunity.

The companion case, College Savings Bank, established the third principle of the Court's modern sovereign immunity jurisprudence. College Savings Bank signaled the death of the constructive waiver theory established in Parden. ${ }^{87}$ Predicated on two assumptions, the constructive waiver theory required that, first, Congress unambiguously provide that a state will be stripped of its immunity if it engages in specific, federally regulated conduct and, second, that the state voluntarily elects to engage in such conduct. ${ }^{88}$ The Court in College Savings Bank was not impressed with this theory and rejected it. ${ }^{89}$ Ultimately, the Court dismissed the Bank's Lanham Act suit for alleged misstatements because it concluded that the Trademark Remedy Clarification Act (TRCA), ${ }^{90}$ like the PRCA, did not validly abrogate Florida's immunity, nor had Florida voluntarily waived its immunity. ${ }^{91}$

While not uncontroversial, scholars' present understanding of Eleventh Amendment jurisprudence is accurately summarized by Professors Mitchell Berman, Anthony Reese, and Ernest Young. They contend that the Court has deviated from the constitutional text by rewriting the Amendment to reflect the following principles: (1) that "state sovereign immunity bars suits based on federal question

${ }^{84} I d$. at $639,646-48$.

${ }^{85}$ Id. at 645 (quoting City of Boerne, 521 U.S. at 526). It is important to keep in mind that at the time of these congressional findings, the conventional understanding among the States was that they were not immune from infringement damages. See supra notes 17-20 (describing the widely held belief that states were subject to damage claims for intellectual property rights infringement). This might explain the lack of any "widespread" deprivation of rights.

${ }^{86} I d$. at 646.

${ }^{87} 527$ U.S. at 680 (stating that the "constructive-waiver experiment of Parden was ill conceived" and that there was "no merit in attempting to salvage any remnant of it”).

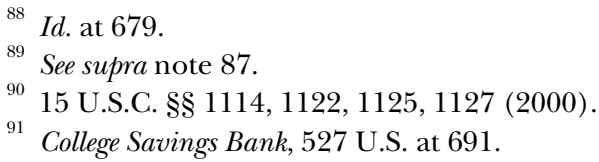


jurisdiction as well as on diversity jurisdiction," eign immunity operates as a federal constitutional bar to jurisdiction even where the suit is brought in state court," ereign immunity can be waived by the state governmental defendant." ${ }^{94}$ Professors Berman, Reese, and Young further assert that the Court's present majority "views state sovereign immunity as a preconstitutional principle, implicit in the constitutional structure, that bars suits against states for money damages. ${ }^{, 95}$

\section{B. The Fallout from Florida Prepaid and College Savings Bank}

It is difficult to understate the impact of Florida Prepaid and College Savings Bank. Since 1999, cases against state universities have been overturned or dismissed, intellectual property holders have behaved strategically, and some courts have engaged in judicial activism.

In light of these decisions, two intellectual property infringement cases against state universities were vacated and eventually dismissed. The first case, Genentech v. Regents of the University of California, ${ }^{96}$ involved a declaratory judgment action by Genentech, a biopharmaceutical company, against the University of California. ${ }^{97}$ Genentech asked the court to declare a University-owned patent invalid and unenforceable and, in the alternative, to declare that Genentech's own patent did not infringe on the University's. ${ }^{98}$ On appeal, the Federal Circuit ruled that because the University chose to "enter the federal arena," had "sole control and initiative" leading up to the dispute, and "invoke[d] . . . federal law and federal judicial power for enforcement of federal property rights," it had waived its immunity. ${ }^{99}$ The Supreme Court disagreed, vacating and remanding the case for reconsideration under College Savings Bank. ${ }^{100}$ Eventually, the case was settled and dismissed in an unpublished opinion by the Federal Circuit. ${ }^{101}$

${ }^{92}$ Berman et al., supra note 21, at 1047.

${ }^{93} I d$.

${ }^{94} I d$.

${ }^{95} I d$. at 1046.

${ }^{96} 143$ F.3d 1446 (Fed. Cir. 1998), vacated and remanded, 527 U.S. 1031 (1999). The parties voluntarily dismissed the suit on remand. Genentech v. Regents of the Univ. of Cal., 230 F.3d 1377 (Fed. Cir. 2000) (unpublished table decision).

${ }^{97}$ Genentech, 143 F.3d at 1449.

${ }^{98} I d$.

${ }^{99} I d$. at 1453 .

${ }^{100}$ Regents of the Univ. of Cal. v. Genentech, 527 U.S. 1031 (1999).

${ }^{101}$ Genentech v. Regents of the Univ. of Cal., 230 F.3d 1377 (Fed. Cir. 2000) (unpublished table decision). 
A second case of state intellectual property infringement was likewise vacated and remanded following Florida Prepaid and College Savings Bank. In Chavez v. Arte Publico Press, ${ }^{102}$ the Fifth Circuit assessed a copyright infringement claim against the University of Houston. ${ }^{103}$ Relying on the Copyright Remedy Clarification Act (CRCA), ${ }^{104}$ passed by Congress in 1990 to expressly hold state entities accountable for monetary damages in intellectual property infringement suits, Chavez argued that the University was liable for publishing her manuscript without consent. ${ }^{105}$ Reflecting on the recent holding in Florida Prepaid, the Fifth Circuit evaluated three aspects of the CRCA to determine whether it satisfied the requirements to abrogate state sovereign immunity: "1) the nature of the injury to be remedied; 2) Congress's consideration of the adequacy of state remedies to redress the injury; and 3) the coverage of the legislation." was an insufficient legislative record of widespread copyright infringement by the states. ${ }^{107}$ Additionally, the Court determined that Congress had failed to consider the availability of state remedies for copyright infringement. ${ }^{108}$ Finally, the Court noted that Congress failed to properly limit the scope of the statute. ${ }^{109}$ Thus, in holding for the University, the Fifth Circuit invalidated the most recent law to create state accountability for intellectual property infringement. ${ }^{110}$

Florida Prepaid and College Savings Bank have also created a deep schism in the array of remedies available to individual plaintiffs against states in intellectual property infringement cases. As the Register of Copyrights testified to Congress last June, "[t] he effect of the Court's 1999 decisions is that copyright owners are unable to obtain monetary relief under the Copyright Act against a State, state entity, or state employee unless the State waives its immunity." true for patent and trademark infringement. ${ }^{112}$

102204 F.3d 601, 603 (5th Cir. 2000).

${ }^{103} I d$. at 603.

104 Pub. L. No. 101-553, 104 Stat. 2749 (1990) (codified as amended at 17 U.S.C. $\S \S 501,511(2000))$.

${ }^{105}$ Chavez, 204 F.3d at 603.

${ }^{106} I d$. at 605.

${ }^{107} I d$. at 605-06.

108 Id. at 606.

109 Id. at 607.

${ }^{110} I d$. at 608.

111 Intellectual Property Protection Restoration Act of 2003: Hearing on H.R. 2344 Before the House Subcomm. on Courts, the Internet, and Intellectual Prop. of the Comm. on the Judiciary, 
As an example of the impact of the diminished remedies, consider the story of Marc Andelman, an amateur inventor who developed a novel method of purifying water. ${ }^{113}$ After obtaining a patent on his invention, he learned that the Department of Energy's Lawrence Livermore National Laboratory was publishing work on a similar technique. ${ }^{114}$ When Andelman confronted the lab, he learned that because it had contracted with the University of California on a joint venture, Livermore and its employees enjoyed the same sovereign immunity as the state university. ${ }^{115}$ While Andelman could pursue a claim for injunctive relief, he would be prohibited from obtaining monetary damages. ${ }^{116}$

In response to these limited remedies, some intellectual property holders may choose to engage in strategic behavior rather than risk being shut out of monetary compensation for infringement altogether. ${ }^{117}$ As Professor Robert Bone has noted, sovereign immunity may lead to strategic choices such as avoiding state universities in favor of private institutions ${ }^{118}$ and maintaining increased secrecy. ${ }^{119} \mathrm{Al}-$ most any strategic behavior may "generate costs of [its] own, even though [it] keep[s] the incidence of actual infringement in check." ${ }^{, 20}$

108th Cong. 10 (2003) [hereinafter Hearing on H.R. 2344] (statement of Marybeth Peters, Register of Copyrights, U.S. Copyright Office) (footnote omitted).

${ }^{112}$ See infra Part IV (discussing legislative attempts to create incentives for states to waive immunity in all areas of intellectual property law).

${ }^{113}$ See David Wolman \& Heather Wax, Putting the Squeeze on State Immunity: Are States Abusing Their Immunity from Intellectual Property Laws?, TECH. REV. (Aug. 21, 2002) (stating that Andelman "spent 11 years developing a new method for water purification using charged material to remove contaminants from dirty water" (citation omitted)), at http://www.technologyreview.com/articles/print_version/wolman08102.asp.

${ }^{114} I d$.

115 Id.

${ }^{116}$ A broader discussion of alternative remedies for state intellectual infringement will be presented in Part IV. For present purposes, it is important to highlight that the immunity recognized by the Supreme Court is immunity against damages relief and that there is no immunity from injunctive relief. Infra text accompanying notes 160-62.

${ }^{117}$ See Robert G. Bone, From Property to Contract: The Eleventh Amendment and University-Private Sector Intellectual Property Relationships, 33 LOY. L.A. L. REV. 1467, 1499 (2000) (arguing that the "simple story" regarding Eleventh Amendment immunity is incomplete because "it ignores the strategic dimension of the interaction between state universities and private parties").

${ }^{118} I d$. at 1504-05 (suggesting that some intellectual property holders may choose to shun state universities and work only with private universities, but later stating that such extreme exclusivity is unlikely because opportunities at the former "are simply too lucrative").

${ }^{119} I d$. at 1505 .

${ }^{120} \mathrm{Id}$. at 1499 . 
The outcome, as Bone suggests, is that "there might be little infringement, yet greater inefficiency in the creative process." ${ }^{121}$

The final impact of the Florida Prepaid and College Savings Bank cases is manifested in the apparent judicial activism occurring in several district courts. While claiming to adhere to the standard set forth in Florida Prepaid and College Savings Bank, federal district courts in California and Ohio have rejected claims of Eleventh Amendment immunity for state universities in intellectual property infringement cases. ${ }^{122}$ In both cases, the court reasoned that the university's acquisition of intellectual property, ${ }^{123}$ which the court held constituted a "gift or gratuity" from the federal government, ${ }^{124}$ was sufficient to waive immunity. ${ }^{125}$ Such decisions are not without critics. Professor John Cross concluded that the district court in New Star Laser "seriously misread the Supreme Court precedent" ${ }^{126}$ by failing to recognize that any Congressional attempt to waive state immunity must be made "unambiguously,' so as to 'enable the States to exercise their choice knowingly." "'27 Notwithstanding this criticism, such rulings suggest that some courts will not tolerate state entities "tak[ing] the good without the bad" by seeking to "enjoy all the benefits of a federal property or right, while rejecting its limitations."

\section{CURRENT CONDITIONS MAKE IMMUNITY FOR STATE UNIVERSITIES INAPPROPRIATE}

Even if the presence of disgruntled intellectual property holders, the threat of strategic behavior, and the potential for judicial activism are all adequate arguments against the Supreme Court's current

121 Id.

${ }^{122}$ See New Star Lasers, Inc. v. Regents of the Univ. of Cal., 63 F. Supp. 2d 1240, 1244 (E.D. Cal. 1999) (denying the University's motion to dismiss because it had waived its immunity by engaging in the patent system); see also McGuire v. Regents of the Univ. of Mich., No. 99-1231, 2000 U.S. Dist. LEXIS 21615, at*12-13 (S.D. Ohio Sept. 21, 2000) (relying on New Star Lasers to deny the University's motion to dismiss on sovereign immunity grounds).

${ }^{123}$ McGuire, 2000 U.S. Dist. LEXIS 21615, at*13 (infringing a trademark); New Star Lasers, 63 F. Supp. 2d at 1241-42 (infringing a patent).

${ }^{124}$ Both McGuire and New Star Lasers relied upon College Savings Bank for the proposition that a "gift or gratuity" resulted in a waiver of immunity. McGuire, 2000 U.S. Dist. LEXIS 21615, at *13; New Star Lasers, 63 F. Supp. 2d at 1244.

${ }^{125}$ McGuire, 2000 U.S. Dist. LEXIS 21615, at*13; New Star Lasers, 63 F. Supp. 2d at 1244.

${ }^{126}$ Cross, supra note 21 , at 363 .

${ }^{127}$ Id. (quoting South Dakota v. Dole, 483 U.S. 203, 207 (1987)).

128 New Star Lasers, 63 F. Supp. 2d at 1244. 
construction of Eleventh Amendment immunity, there are additional reasons why its interpretation is not appropriate. As discussed in Part I, universities have a history of acquiring intellectual property rights and collaborating with private firms to commercialize such property. ${ }^{129}$ But recent developments in the market and changes in the law have altered the dynamics of this acquisition and commercialization in such a way as to make state universities' immunity from damage suits for intellectual property infringement improper. These changes include the increasing financial importance of intellectual property for state universities, a higher reliance on courts to enforce state universities' intellectual property rights against infringement, and a tightening of the fair use and research exemptions.

Notwithstanding their nonprofit status, one should not begrudge universities for trying to capitalize on a lucrative asset-their intellectual property. The commercial value of university-held patents, copyrights, and trademarks is enough to excite any university's technology transfer office. ${ }^{130}$ Interestingly, intellectual property is a relatively new revenue generator for universities. Prior to the passage of the BayhDole Act in 1980, fewer than 250 patents per year were issued to universities. ${ }^{131}$ In 2002, that number exceeded $3000 .{ }^{132}$ The licensing of university-owned intellectual property has experienced a similarly remarkable increase. Between 1991 and 1999, universities' "annual invention disclosures increased $63 \%$ (to 12,324 ), new patents filed increased $77 \%$ (to 5,545) and new licenses and options executed increased $129 \%$ (to 3,914)." 133 Perhaps even more impressive is that nearly $\$ 1$ billion in gross revenue is received by universities annually for licensing and transferring their intellectual property. ${ }^{134}$

Multiple forces have driven this increasing emphasis on intellectual property as a revenue source for universities. Focusing on patents, Professor Rebecca Eisenberg has suggested that "[p]erhaps the simplest explanation is that the Bayh-Dole Act gave universities a

129 See supra text accompanying notes 8-16 (describing the profitable nexus between universities and private industry in intellectual property matters).

${ }^{130}$ See infra text accompanying note 134 (noting that the annual collective value of university-owned intellectual property approaches one billion dollars).

131 Ass'n of Univ. Tech. Managers, Surveys-Common Questions E Answers About Technology Transfer, at http://www.autm.net/pubs/survey/qa.html (last updated Nov. $13,2000)$.

${ }^{132}$ See Ass'N OF UNIV. TECH. MANAGERS, supra note 12, at 62 (reporting that 3109 U.S. patents were issued to universities in 2002).

133 Ass'n of Univ. Tech. Managers, supra note 131.

134 Ass'N OF UNIV. TECH. MANAGERS, supra note 12, at 62. 
revenue motive to pursue patent rights, and this revenue motive has taken on a life of its own ...." ${ }^{, 135}$ She also has noted that although few universities profited from their intellectual property rights as of 1996, "many of them have great expectations, and they feel fully justified in using their patent rights to bring in as much revenue as they can."136

In addition to the incentives provided by the Bayh-Dole Act, state universities have other reasons for going commercial. As Professor Peter Menell has articulated, there are at least three additional factors that have encouraged state universities to exploit their intellectual property assets: a decrease in state budget allocations for universities, a decline in the growth rate of federal funding for tertiary educational institutions, and a rising uncertainty about reliance upon all forms of government funding. ${ }^{137}$ Driven by funding shortfalls, state universities are motivated to exploit their intellectual property.

With exploitation, however, comes litigation. While the University of Rochester ${ }^{138}$ and Duke University ${ }^{139}$ cases discussed in the Introduction highlight the general nature of the intellectual property infringement claims against universities, it is useful to consider the U.S. General Accounting Office's (GAO) comprehensive study of intellectual property suits against state entities. ${ }^{140}$ Generated for the Senate Judiciary Committee, the GAO report evaluated state immunity in regard to intellectual property actions, paying particular attention to the consequences of Florida Prepaid and College Savings Bank. ${ }^{141}$ Although there were several caveats to its findings, ${ }^{142}$ the GAO concluded that

${ }^{135}$ Eisenberg, supra note 14, at 1722.

${ }^{136} I d$. at $1722-23$.

${ }^{137}$ Peter S. Menell, Economic Implications of State Sovereign Immunity from Infringement of Federal Intellectual Property Rights, 33 LOY. L.A. L. REV. 1399, 1434 (2000).

${ }^{138}$ Univ. of Rochester v. G.D. Searle \& Co., 249 F. Supp. 2d 216 (W.D.N.Y. 2003), aff'd, 358 F.3d 916 (Fed. Cir. 2004).

${ }^{139}$ Madey v. Duke Univ., 307 F.3d 1351 (Fed. Cir. 2002), cert. denied, 123 S. Ct. 2639 (2003).

${ }^{140}$ U.S. Gen. ACCOUnTING OfFICE, supra note 11.

${ }^{141}$ See id. at 1 (discussing Florida Prepaid, 527 U.S. 627 (1999), and College Savings Bank, 527 U.S. 666 (1999)).

${ }^{142}$ Calculating the actual number of intellectual property cases involving a state entity as a defendant is complicated for several reasons. First, some suits involving intellectual property infringement are brought under different causes-of-action. U.S. Gen. ACCOUnTING Office, supra note 11, at 8 . Second, identifying a state entity by name is not a foolproof filter because some nonstate entities carry a state name in their titles (e.g., California Institute of Technology, University of Pennsylvania), whereas legitimate state entities may not have the name of the state in their title (e.g., Auburn University, Rutgers University). Id. Third, state officials are "more likely to handle an 
since 1985, there had been fifty-eight cases involving intellectual property infringement where a state entity was a defendant ${ }^{143}$ and forty-two cases where a state entity was a plaintiff. ${ }^{144}$ Of the fifty-eight suits where a state entity was a defendant, thirty-two involved a state institution of higher learning. ${ }^{145}$ In a related finding, the Software and Information Industry Association (SIIA) claimed that, between 1995 and 2001, it handled seventy-seven "matters" involving a state entity; about half of these involved a state institution of higher learning. ${ }^{146}$

As market forces motivate state universities to compete for funds to develop intellectual property, statutory and case law amplify the inequity of the Supreme Court's interpretation of the Eleventh Amendment. Specifically, the fair use and research exemption doctrines are being winnowed away by Congress and the courts. ${ }^{147}$ For example, the Digital Millennium Copyright Act $^{148}$ proscribed nearly all previously available fair use of digital information. ${ }^{149}$ In addition, the recent Federal Circuit decision in Madey v. Duke University ${ }^{150}$ essentially eviscerated any remnant of a research exemption for universities. ${ }^{151}$

accusation of intellectual property infringement administratively" before the dispute reaches the litigation stage. $I d$. at 12 .

${ }^{143} I d$. at 2, 10 tbl.1.

144 Id. at 11 .

${ }^{145} I d$. at 10 tbl.1.

${ }^{146} I d$. at 13. SIIA refers to these infringement cases as "matters" because they rarely involve litigation; the state entity usually pays a penalty and complies with the law once notified of its infringement. Id.

${ }^{147}$ This Comment does not provide a thorough review of these doctrines and their related case law. However, such an analysis may be found in Pamela Samuelson, Intellectual Property and the Digital Economy: Why the Anti-Circumvention Regulations Need To Be Revised, 14 Berkeley TECH. L.J. 519 (1999); Bentley J. Olive, Anti-Circumvention and Copyright Management Information: Analysis of New Chapter 12 of the Copyright Act, 1 N.C. J.L. \& TECH. 19 (2000).

${ }^{148}$ Pub. L. No. 105-304, 112 Stat. 2860 (1998) (codified at 17 U.S.C. $§ \S 1201-1205$ (2000))

${ }^{149}$ See 17 U.S.C. $\$ 1201$ (2000) (providing limited exemptions to fair use where an entity circumvents technological measures controlling access to a protected work).

${ }_{150} 307$ F.3d 1351 (Fed. Cir. 2002), cert. denied, 123 S. Ct. 2639 (2003).

${ }^{151}$ See James Boyle, Foreward: The Opposite of Property, LAW \& CONTEMP. Probs., Winter/Spring 2003, at 1, 27 (noting that the Federal Circuit has further limited the already "crabbed U.S. research exemption" through its Madey ruling); Natalie M. Derzko, In Search of a Compromised Solution to the Problem Arising from Patenting Biomedical Research Tools, 20 SANTA CLARA COMPUTER \& High TECH. L.J. 347, 361 (2004) (asserting that Madey and other recent developments in patent law have made the research exemption "essentially unavailable" to university researchers); Tom Saunders, Comment, Renting Space on the Shoulders of Giants: Madey and the Future of the Experimental Use Doctrine, 113 YALE L.J. 261, 261 (2003) (stating that Madey "reformulated the experimental use doctrine and cast considerable doubt on its continued viability as a defense in patent 
After Madey, no exemption will be recognized, even for noncommercial research, if it "further[s] the institution's legitimate business objectives ...." Rather, the use must be "solely for amusement, to satisfy idle curiosity, or for strictly philosophical inquiry...." ${ }^{153}$ The impact of tightening the fair use and research exemption doctrines may not yet be fully appreciated, but it will undoubtedly affect both private and public universities. Fortunately for state universities, they have a safety net in the Eleventh Amendment. Even if traditional fair use and research exemptions do not protect the state universities, they can rely on their sovereign immunity to limit their exposure to monetary damages for infringement.

The resulting combination of increased commercialization, frequent litigation, reduced fair use and research exemptions, and robust Eleventh Amendment immunity gives state universities a potentially strong financial advantage over their private counterparts. Professor Mark Lemley best summarized the present situation's inherent unfairness when he complained that the sovereign immunity doctrine as applied to intellectual property is "manifestly unfair because it protects States from the rules of the market even when those States participate in the market." ${ }^{154}$ As he correctly emphasized, in the context of intellectual property infringement, state universities are not behaving as sovereigns in the intellectual property market; they are behaving as market participants who should be held to the same standards and rules as other similarly situated participants. ${ }^{155}$

Many commentators have warned that the environment is ripe for the wholesale infringement of intellectual property rights by state entities. The Register of Copyrights has said that "logic dictates that if a

infringement cases involving universities"). See generally David L. Parker, Patent Infringement Exemptions for Life Science Research, 16 HOUS. J. INT'L L. 615, 626-38 (1994) (summarizing the history of the research exemption in the United States).

${ }^{152} 307$ F.3d at 1362 .

153 Id.

${ }^{154}$ Hearing on State Sovereign Immunity, supra note 8, at 72 (statement by Mark A. Lemley, Professor of Law, University of California at Berkeley) (explaining the unfairness of the current state sovereign immunity doctrine in the context of intellectual property law).

${ }_{155}$ Id. In College Savings Bank, interestingly, the Supreme Court rejected the state agent's reliance on the "market participant" cases, which the government used to argue that when states act as private market participants, they should be treated as any other market participant. 527 U.S. 666, 684-85 (1999). In finding that the "market participant" exception is not appropriate to a case of sovereign immunity, the Court emphasized that, in such contexts, "'[e]venhandness' [sic] between individuals and States is not to be expected ...." Id. at 685 . 
segment of people will not be held fully accountable for certain actions, they may be less likely to restrict themselves in those actions."156 The National Association of College and University Attorneys concurs in this prediction: "Given the dramatic reduction in the checks against State infringement, it is only logical that the result will be increased but unremedied infringements." ${ }^{\text {E57 }}$ Even Professor Menell, who provides an exhaustive rebuttal to this position, concedes that as universities are "drawn ... into the commercial sphere, [it] inevitably raises the potential for infringement of intellectual property rights." 158

\section{Proposed Alternative SOlutions For Intellectual Property INFRINGEMENT BY STATE UNIVERSITIES}

Even after the Supreme Court's holdings in Florida Prepaid and College Savings Bank, plaintiffs bringing intellectual property infringement suits against state entities still have limited remedies available, though monetary relief is not one of them. In addition to these circumscribed remedies, Congress has considered several bills that abrogate and/or waive state sovereign immunity from monetary damages in intellectual property infringement cases. The most recent attempt has been led by Senator Leahy, who introduced the Intellectual Property Protection Restoration Act of 2003 (S. 1191). ${ }^{159}$

At present, remedies available to intellectual property holders include injunctive relief, state-defined relief for claims of inverse condemnation, tort, breach of license or contract, and state intellectual property law. ${ }^{160}$ Frequently, however, these remedies are less preferable than damage awards. For example, Professor Berman points out that even when a state infringement appears to constitute a Fifth

${ }^{156}$ Hearing on H.R. 2344, supra note 111, at 11.

${ }^{157}$ Nat'l Ass'n of Coll. \& Univ. Attorneys, supra note 20, at 1.

${ }^{158}$ Menell, supra note 137, at 1433. Although not discussed in this Comment, increasing university participation in the commercial sphere may create an additional area of concern; private entities, which would otherwise be subject to monetary damages for infringement, may seek to collaborate with state universities so that any intellectual property infringement committed by the collaborative entity would be shielded from damage claims. Cf. supra text accompanying notes 113-16 (noting that the Lawrence Livermore National Laboratory was immune from infringement-related damage claims because it collaborated with a state university in its research).

${ }^{159}$ S. 1191, 108th Cong. (2003).

${ }^{160}$ See Malin, supra note 21, at 164-65 (providing a comprehensive list and discussion of post-Florida Prepaid state infringement remedies); Menell, supra note 137, at 1413-28 (discussing state causes of action available for intellectual property infringement). Relief under state intellectual property law is only available if the state provisions do not duplicate the federal intellectual property laws. Id. at 1422. 
Amendment taking justifying compensation, ${ }^{161}$ it is "far from clear at the present time... how often and under what circumstances an act of infringement will qualify as a taking." ${ }^{162}$

Because of this uncertainty, Senator Leahy has introduced S. 1191 in an attempt to close the perceived loophole in intellectual property laws created by the Supreme Court's interpretation of the Eleventh Amendment. This bill is not Senator Leahy's first proposal to protect intellectual property. In 1999, he introduced the Intellectual Property Protection Restoration Act of 1999 (S. 1835). ${ }^{163}$ The key provision of S. 1835 denied states and state instrumentalities the ability to acquire federal intellectual property rights until they opted into the federal intellectual property system. ${ }^{164}$ Opting into that system required the state to "waive sovereign immunity from suit in Federal court in any action against the State or any instrumentality or official of that State," including state universities. ${ }^{165}$

Although the bill was never passed, it received considerable attention from academics. ${ }^{166}$ In general, there was widespread recognition that S. 1835's reliance on state waiver of immunity, as opposed to straight abrogation of such immunity by Congress, was a significant advantage. ${ }^{167}$ Proponents of the bill argued that state waiver of immunity would be both superior to abrogation and more likely to survive constitutional scrutiny by the courts, ${ }^{168}$ so long as the waiver was "voluntary and unequivocal" ${ }^{169}$ and involved a benefit that the state would be "unable to realize ... without Congress's prior approval."170

S. 1835 did have some detractors. Professor Cross criticized the bill and said that it would likely fail the germaneness standard. ${ }^{171}$ The

${ }^{161}$ U.S. CONST. amend. V (providing that "private property shall not be taken for public use, without just compensation").

${ }^{162}$ Berman et al., supra note 21, at 1072.

${ }^{163}$ S. 1835, 106th Cong. (1999).

${ }^{164}$ Id. $\S 111(\mathrm{a})$.

${ }^{165} I d . \S 111(\mathrm{~b})$.

${ }^{166}$ See, e.g., Berman et al., supra note 21; Cross, supra note 21; Malin, supra note 21.

${ }^{167}$ See Berman et al., supra note 21, at 1130 (referring to the "obvious advantage" of S. 1835 because the use of a waiver avoids any of the "complicated requirements for abrogation" established by the Court); Bohannan, supra note 21, at 341 (presenting several arguments for why federal and state governments should be permitted to "bargain over sovereign immunity").

${ }^{168}$ Bohannan, supra note 21, at 304.

${ }^{169}$ Id.

${ }^{170} I d$. at 325.

${ }^{171}$ Cross, supra note 21, at 385-86. Although a complete discussion of the germaneness doctrine is not provided in this Comment, additional explanation can be found in 
germaneness analysis seeks a connection between the condition imposed by the legislation and the expected benefit. ${ }^{172}$ In arguing that $S$. 1835 would fail a test for germaneness, Cross condemned the waiver condition as not truly connected to the benefit of abrogating immunity because " $[\mathrm{t}]$ he condition that $[\mathrm{S} .1835]$ would place on that benefit . . . applies not to the State's own creative activity, but instead protects the creative activity of others." ${ }^{173}$ Other scholars argued that the bill would have a significant impact on nonconsenting states. For example, Steve Malin has suggested that it might be difficult for nonconsenting states to attract preeminent researchers to their state universities because such researchers would be unable to protect their intellectual property. ${ }^{174}$ Professor Berman identified a separate weakness of S. 1835 . He noted that the penalty imposed by the bill—denial of any intellectual property rights protection-was "more severe than necessary to equalize the positions of non-waiving states and their private competitors." ${ }^{175}$ An alternative, he suggested, would be "to grant intellectual property protection even to non-waiving states, but to limit their remedies to those that would be available in suits against them."176

In 2003, Senator Leahy revised the proposed Intellectual Property Protection Restoration Act and introduced a much more specific and targeted proposal (S. 1191)..$^{177}$ An identical companion bill was introduced in the House of Representatives by Representatives Lamar Smith

David Cole, Beyond Unconstitutional Conditions: Charting Spheres of Neutrality in Government-Funded Speech, 67 N.Y.U. L. REV. 675 (1992); Brooks R. Fudenberg, Unconstitutional Conditions and Greater Powers: A Separability Approach, 43 UCLA L. REV. 371 (1995); Albert J. Rosenthal, Conditional Federal Spending and the Constitution, 39 STAN. L. REV. 1103 (1987); Kathleen M. Sullivan, Unconstitutional Conditions, 102 HARV. L. REV. 1415 (1989); and Cass R. Sunstein, Why the Unconstitutional Conditions Doctrine is an Anachronism (With Particular Reference to Religion, Speech, and Abortion), 70 B.U. L. REV. 593 (1990).

${ }^{172}$ Cross, supra note 21, at 385 . Cross believes the germaneness analysis is relevant whenever Congress seeks to bestow a benefit. Id. at 386 .

${ }^{173} I d$. at $385-86$.

${ }^{174}$ Malin, supra note 21, at 189.

${ }^{175}$ Berman et al., supra note 21, at 1160.

${ }^{176} I d$.

177 See 149 CONG. REC. S7479-80 (daily ed. Jun. 5, 2003) (statement of Sen. Leahy) (introducing S. 1191 and describing it as a refinement of the bill's predecessor, S. 1835). Between S. 1835 in 1999 and S. 1191 in 2003, Senator Leahy introduced two other bills seeking to protect intellectual property. Intellectual Property Protection Restoration Act of 2002, S. 2031, 107th Cong. (2002); Intellectual Property Protection Restoration Act of 2001, S. 1611, 107th Cong. (2001). S. 1611 was identical to S. 2031, with the exception that the latter was cosponsored by Sen. Sam Brownback in 2002. S. 2031 was identical in substance to S. 1911. 
and Howard Berman (H.R. 2344).$^{178}$ These bills have four purposes: (1) to "eliminate the unfair commercial advantage that States and their instrumentalities now hold," (2) to "promote technological innovation and artistic creation," (3) to "reaffirm the availability of prospective relief against State officials," and (4) to "abrogate State sovereign immunity in cases where States or their instrumentalities, officers, or employees violate the United States Constitution by infringing Federal intellectual property." ${ }^{\text {"179 }}$ Senator Leahy has stated that he considers it intolerable that "some participants in the intellectual property system get legal protection but need not adhere to the law themselves," arguing that a change in the status quo must be made if fairness is truly valued. ${ }^{180}$

S. 1191 has three core provisions that are noticeably different than its 1999 predecessor bill. The first provision precludes monetary relief for a state or state entity for infringement of its intellectual property unless the state has waived its immunity. ${ }^{181}$ Accordingly, a non-waiving state is limited to the same remedies afforded to individual plaintiffs whose intellectual property is infringed by the state. The second provision of S. 1191 clarifies the remedies available for statutory violations by a state officer or employee; it provides that "remedies shall be available against the [state] officer or employee in the same manner and to the same extent as such remedies are available in an action against private individuals under like circumstances." ${ }^{\text {,182 }}$ The final provision of the bill allows actual damages from any state for due process or takings violations involving intellectual property. ${ }^{183}$

Senator Leahy is optimistic that his bill is both attractive to states and constitutional under current Supreme Court jurisprudence. He reasons that his bill offers options to states: "It creates reasonable incentives for States to waive their immunity in intellectual property cases, but it does not oblige them to do so." ${ }^{184}$ He argues that this revised bill is constitutional because "Congress may attach conditions to

${ }^{178}$ Intellectual Property Protection Restoration Act of 2003, H.R. 2344, 108th Cong. (2003).

${ }^{179}$ S. 1191 § 2; H.R. $2344 \S 2$.

180 CONG. REC. S7479, S7479-80 (daily ed. Jun. 5, 2003) (statement of Sen. Leahy).

${ }^{181}$ See S. $1191 \S 3$ (amending laws covering patents, copyrights, and trademarks to require a waiver of state sovereign immunity prior to allowing damages for infringement).

${ }^{182} I d . \S 4$.

${ }^{183} I d . \S 5$.

184149 CONG. REC. S7480 (statement of Sen. Leahy). 
a State's receipt of Federal intellectual property protection under its Article I property power just as Congress may attach conditions on a State's receipt of federal funds under its Article I spending power." ${ }^{185}$ Since the bill is still being vetted by politicians and interested parties, it is too early to know whether either of Senator Leahy's contentions will hold true.

What is clear is that both supporters and opponents of S. 1191 appear to be retrenching for a contentious mêlée. Supporters of the bill include the Copyright Office, the American Bar Association, the American Intellectual Property Law Association, the Business Software Alliance, the Intellectual Property Owners Association, the International Trademark Association, the Motion Picture Association of America, the Professional Photographers of America Association, and the U.S. Chamber of Commerce. ${ }^{186}$ These organizations consider the bill "carefully balanced" ${ }^{187}$ and an example of "legislation that would as a matter of fairness and in the interest of consumer protection hold states and state entities to the same principles of law as the private sector." 188 In addition, it is likely that the bill has two strong advocates representing academic interests: the American Association of University Professors (AAUP) and the National Association of College and University Attorneys (NACUA). Both organizations have voiced support for liability for state university infringement on private intellectual property holders' rights. In its June 2002 position paper on intellectual property, the AAUP states that, contrary to the administration of many universities, it supports "this basic restoration of a level playing field to intellectual property law." timent by claiming that Leahy's bill will help to "restore the balance of

${ }^{185} I d$. (statement of Sen. Leahy); see also U.S. CONST. art I, § 8, cl. 8 (granting Congress the power "to promote the progress of Science and useful Arts, by securing for limited Times to Authors and Inventors the exclusive Right to their respective Writings and Discoveries").

${ }^{186} 149$ CONG. REC. S7480 (statement of Sen. Leahy) (mentioning that these organizations publicly support his bill).

${ }^{187}$ Hearing on H.R. 2344, supra note 111, at 6 (statement of Marybeth Peters, Register of Copyrights, U.S. Copyright Office) (describing the Copyright Office's support of the Intellectual Property Protection Restoration Act H.R. 2344).

${ }^{188}$ Letter from Kathryn Barrett Park, President, International Trademark Association, to Lamar Smith, Chairman, House Subcomm. on Courts, the Internet and Intellectual Prop., Committee on the Judiciary (June 13, 2003), available at http://www. inta.org/policy/test_abrogation.html.

${ }^{189}$ Am. Ass'n of Univ. Professors, Intellectual Property: An AAUP Position Paper, at http://www.aaup.org/govrel/capthill/2002/02ip.htm (June 2002). The AAUP's paper deals with S. 2031, which is identical to S. 1191 in virtually all aspects. Supra note 178. 
intellectual property protection and level the playing field by encouraging States to waive their sovereign immunity." 190

Just as the Supreme Court seems unimpressed with "abstract concerns such as fairness" ${ }^{191}$ when it comes to sovereign immunity, opponents of S. 1191 (and its predecessors) dispute the "level playing field" argument. Leading the charge against the bill are the Association of University Technology Managers, ${ }^{192}$ the National Association of State Universities and Land-Grant Colleges, ${ }^{193}$ and the American Council on Education. ${ }^{194}$ These opponents share a common concern that, as state entities, the bill will subject them to liability for actual damages, but, because they lack the persuasive power necessary to convince their state to waive immunity to suit, they will be precluded from receiving damages for infringement on their own intellectual property.

${ }^{190}$ Nat'l Ass'n of Coll. \& Univ. Attorneys, supra note 20, at 1.

191 See Bohannan, supra note 21, at 302 ("Given the Court's recent abrogation decisions ... it may seem unrealistic to suggest that abstract concerns such as fairness or the rule of law will trump the Court's calculus of sovereign immunity in evaluating waivers.").

${ }^{192}$ See Letter from Janet E. Scholz, President, Association of University Technology Managers, Inc., to Patrick J. Leahy, Chairman, Committee on the Judiciary, United States Senate, and Orrin G. Hatch, Ranking Member, Committee on the Judiciary, United States Senate (May 16, 2002), available at www.autm.net/announcements/ s2031letter.pdf (noting the Association's "strong opposition to" S. 2031, which is identical to S. 1911 and H.R. 2344, for being "internally inconsistent" by attempting to promote innovation while also barring state entities from obtaining intellectual property rights without waiver). Neither S. 1191 nor its predecessor, S. 2031, however, limits the availability of intellectual property protection for state entities. Rather, these bills limit the ability of a state entity to collect monetary damages. Supra note 181 and accompanying text. Thus, it appears that the Association of University Technology Managers is reacting to S. 1835, not the revised 2002 or 2003 version of that bill. See Intellectual Property Protection Restoration Act of 1999, S. 1835, § 111, 106th Cong. (1999) ("No State or any instrumentality of that State may acquire a Federal intellectual property right unless that State opts into the Federal intellectual property system.").

See Letter from C. Peter Magrath, President, National Association of State Universities and Land-Grant Colleges, to Patrick J. Leahy, Chairman, Committee on the Judiciary, United States Senate 1 (Apr. 17, 2002), available at http://www.nasulgc. org/Washington_Watch/Letters2002/S2031_state_sovereign_immunity.pdf (opposing S. 2031 and requesting a delay in the legislative process so that it can help redraft the legislation).

${ }^{194}$ See Richard Morgan, Colleges Step Up Lobbying Against Proposed Intellectual-Property Legislation, Chron. Higher Educ. (Apr. 23, 2002) (stating that Sheldon E. Steinbach, the Vice President and General Counsel of the American Council on Education, "said that the bill's [S. 2031] current language would put colleges in a 'diminished' and 'compromised' position as owners of intellectual property"), at http://chronicle.com/ prm/daily/2002/04/2002042301n.htm. 
Accordingly, they believe they will be unduly punished. ${ }^{195}$ For such opponents, a preferred version of this bill would allow a state to make a piecemeal waiver of its immunity (e.g., waive the immunity for certain entities). ${ }^{196}$

\section{The Intellectual Property Protection Restoration ACT OF 2003: THE OPTIMAL SOLUTION}

The current version of the Intellectual Property Protection Restoration Act, S. 1191, is the optimal solution to the problems of the intellectual property regime created by Florida Prepaid and College Savings Bank. The bill should be passed by Congress and supported by state universities.

Congress should adopt S. 1191 as introduced in June 2003 by Senator Leahy and Representatives Berman and Smith for three reasons. First, the bill successfully avoids the straight abrogation approach, and the attendant constitutional problems, that were ridiculed in Florida Prepaid. Leahy's bill gives states a choice: They can either waive their Eleventh Amendment immunity or forego monetary damages in their own suits against intellectual property infringers. ${ }^{197}$ The bill is thus unambiguous, completely voluntary, and concerns a benefit-monetary relief for intellectual property suits-that only the federal government can grant. Under this bill, each state can calculate the relative costs and benefits of waving its sovereign immunity.

The bill's emphasis on remedies, rather than intellectual property rights more broadly, overcomes the constitutional objections of Malin

${ }^{195}$ See Letter from Janet E. Scholz to Patrick J. Leahy and Orrin J. Hatch, supra note 192, at 2 (arguing that there is no reason to believe that a state would waive its immunity to appease a university technology transfer office); Letter from C. Peter Magrath to Patrick J. Leahy, supra note 193, at 1 (claiming that it is "highly unlikely that [public universities] can convince state legislatures to waive immunity for all state entities”); Email from Mani Iyer, Director, Office of Intellectual Property, Louisiana State University, to Techno-L@lists.uventures.com (Mar. 21, 2002, 12:03PM CST) (maintaining that the bill, if passed, "would put state universities in the untenable position of trying to persuade their respective legislatures to allow such suits against the entire state government ... when universities are usually the only state agencies that directly benefit from technology transfer efforts"), available at http://lists.essential.org/ pipermail/ip-health/2002-April/002861.html.

${ }^{196}$ But see Nat'l Ass'n of Coll. \& Univ. Attorneys, supra note 20 (criticizing the "entity-by-entity approach" to immunity waiver as "encourag[ing] gamesmanship by a State that could arrange for all the State's intellectual property rights to be owned by particular entities").

${ }^{197}$ Intellectual Property Protection Restoration Act, S. 1191, §§ 3-4, 108th Cong. (2003); see also supra text accompanying notes 181-82 (describing the effect of S. 1835). 
and Professors Cross and Berman. There is a strong showing of germaneness between the waiver and the goal as the state's waiver of sovereign immunity triggers the possible benefit of being allowed to seek monetary relief in its own infringement suits. In addition, both the waiver and the benefit are well-aligned with Congress's goal of equalizing the relief available to state and private plaintiffs in intellectual property disputes. Finally, the bill does not overly penalize nonwaiving states or their entities. Under the bill, nonwaiving states may still obtain intellectual property rights and protection; they simply will be foreclosed from seeking monetary damages.

Second, the bill injects a shot of fairness into the intellectual property system that is otherwise subject to abuse by states and their entities. Given the increasing commercialization of state universities, the subsequent litigation activity between state universities and private parties, and the narrowing of available fair use and research exemption provisions, proactive legislation is needed to ensure that state entities do not unfairly take advantage of sovereign immunity to the detriment of other intellectual property holders. An imbalanced system will create disincentives to innovate for persons like Mark Andelman, will lead to strategic behavior by private parties dealing with state entities, and may encourage further judicial activism, resulting in inconsistent interpretations of the law regarding sovereign immunity. Fairness and equity in intellectual property do matter, and Congress should consider them.

Third, Congress should adopt this bill because of its timeliness. As several commentators have warned, there is a clear danger that states may increase their infringement upon privately held intellectual property rights because of the affirmation of their immunity from monetary damages in infringement suits. S. 1191 provides a timely stopgap measure to limit state infringement. Adoption of S. 1191 would also give Congress additional time to analyze the scope and trend of intellectual property infringement by states. Should the bill's provisions prove insufficient to curb state infringement, then a more thorough analysis conducted while S. 1191 is in effect may provide sufficient justification for outright congressional abrogation of state immunity.

While these three justifications should persuade Congress to pass S. 1191 into law, there is, of course, the obvious concern that the incentive of monetary relief may not be sufficient to persuade some states to waive their immunity. It is possible that a state may decide to forego the benefits of monetary relief for the assurances of immunity 
from such claims. For this reason, it is critically important that state universities support the bill and encourage their legislatures to voluntarily waive their immunity.

State universities have four incentives to support S. 1191. First, and fundamentally, the proposal places no additional burdens on technology transfer offices or the researchers and creators at universities. The bill simply ensures a neutral environment for bargaining and innovating. Second, as passed, the bill will give teeth to existing university policies that prohibit infringement of private intellectual property rights. ${ }^{198}$ Without this bill, there is very little to prevent a state university researcher, instructor, or creator from infringing another person's intellectual property right. Third, unlike a piecemeal approach to waiver, a complete and broad waiver by a state of sovereign immunity from intellectual property suits will ensure a manageable and consistent environment regarding immunity. As the GAO found when analyzing the number of infringement suits involving state entities, knowing when an entity is eligible for sovereign immunity and when it is not can be a thorny endeavor. ${ }^{199}$ By making all entities-whether privately or publicly funded—subject to liability for monetary damages in intellectual property infringement suits, the bill provides certainty to intellectual property holders that their rights will be fully protected. The fourth and final reason that state universities should support S. 1191 is the opportunity it gives them to demonstrate their influence on their state legislators. Across the board, intellectual property holders have tremendous political power. ${ }^{200}$ Given their impressive intellectual property holdings, it is quite conceivable that state universities would have an equally tremendous impact; any argument to the contrary undermines the inherent influence that state universities possess. ${ }^{201}$ Ultimately, the support by state universities for

198 See, e.g., UnIV. OF TEX. Sys., InTEllectual Property Policy \& Guidelines (rev. ed. 1999), available at http://www.utsystem.edu/ogc/IntellectualProperty/ polguide.htm (establishing guidelines for creating and using intellectual property); UNIV. OF CAL., UNIVERSITY OF CALIFORNIA POLICY ON THE REPRODUCTION OF COPYRIGHTED MATERIALS FOR TEACHING AND RESEARCH (1986), available at http:// www.ucop.edu/ucophome/coordrev/policy/4-29-86.html\#guide (providing "direction on photocopying of copyrighted materials for teaching and research").

199 Supra note 142.

200 See Menell, supra note 137, at 1438 (asserting that, "[a]s a class, intellectual property owners have tremendous political clout").

201 Such influence is realized in several ways. For example, the fact that congressional appropriations exceeding $\$ 2$ billion in fiscal year 2003 is persuasive evidence that state universities have significant political clout. These federally funded academic earmarks represent a ten percent increase over previous year's appropriations, suggesting 
S. 1191 will ensure that states do not choose to sidestep this fair and needed legislation.

\section{CONCLUSION}

At a time when state universities are becoming increasingly commercialized, immunity from monetary damages is no longer appropriate. By collaborating with private entities, reaping millions of dollars in licensing revenue, and seeking monetary relief for infringement by private parties, state universities have demonstrated their desire and ability to operate similarly to private entities. Consequently, it seems unconscionable that state universities should be allowed to hide from monetary damages in infringement suits.

Nevertheless, so long as state universities are allowed to invoke Eleventh Amendment immunity to deflect monetary damages in infringement suits, there will be an injustice to both private universities and to intellectual property holders whose rights are infringed by state universities. Private universities are disadvantaged because, unlike state universities, monetary damage awards threaten their financial interests, a threat amplified by recent narrowing of the fair use and research exemption doctrines. Intellectual property holders are likewise disadvantaged because they lack access to monetary relief when state universities infringe their patents, copyrights, or trademarks.

This cabining of monetary relief is not only inequitable, it has created several additional negative consequences, including frustration and resentment among entities that remain subject to monetary damages, disincentives to innovate, strategic behavior by intellectual

that state universities have been increasingly successful in their lobbying efforts of Congress. For further discussion, see Jeffrey Brainard \& Anne Marie Borrego, Academic Pork Barrel Tops \$2-Billion for the First Time, Chron. Higher Educ., Sept. 26, 2003, at A18.

Additionally, studies such as the one conducted by the Huron Consulting Group for North Carolina's public universities, detail state universities' impact on the overall economy of a state. See Huron Consulting Group, Enhancing the Ability of North Carolina's Public Research Universities to Contribute to State ECONOMIC DEVELOPMENT (2004), available at http://www.unc.edu/news/newsserv/ archives/mar04/ncstate/huronreport.doc. In that study, Huron concluded that the State of North Carolina benefited by as much as $\$ 930$ million from the "transformation of Federal funds [received by state universities] into revenue for local residents and North Carolina businesses." Id. at 8-9. North Carolina also enjoyed stable employment rates and attracted new businesses, some of which developed new technologies, because of the state universities. Id. at 9-10. As the Huron study demonstrates, public universities have considerable economic impact on states; thus, it follows that they command some influence with state and federal legislatures. 
property holders dealing with state entities, and judicial activism. Left unchanged, some scholars warn that state entities may actually infringe intellectual property with greater frequency since there is no financial deterrent preventing them from so doing. Indeed, given the financial value of intellectual property licensing by universities, it is easy to appreciate a state university's potential incentives to infringe when pursuing a new technology or innovation.

To redress this unfairness, Congress should enact the Intellectual Property Protection Restoration Act of 2003. Unlike earlier proposals, S. 1191 gives states the choice to either waive their immunity in intellectual property suits or risk being denied monetary relief for infringement of their own state-owned intellectual property. In this way, S. 1191 avoids the obstacle of immunity abrogation, and instead, permits each state to determine whether the benefit of waiving immunity is balanced by the potential cost of monetary damages.

The Intellectual Property Protection Restoration Act of 2003 is vitally necessary in this era of state university commercialization. Such legislation will help redistribute the risk of infringement back on state entities, thereby ensuring that all infringers-whether public or private-are subject to a level playing field for intellectual property rights. 